\title{
An Amphitropic cAMP-Binding Protein in Yeast Mitochondria. 2. Phospholipid Nature of the Membrane Anchor ${ }^{\dagger}$
}

\author{
Günter Müller*,‡ and Wolfhard Bandlow ${ }^{\S}$ \\ Laboratorium für molekulare Zellbiologie und allgemeine Pathologie, Institut für Pathologie und Rechtsmedizin der Universität \\ Ulm, Neuherbergstrasse 11, D-8000 München 45, Federal Republic of Germany, and Institut für Genetik und Mikrobiologie der \\ Universität München, Maria-Ward-Strasse la, D-8000 München 19, Federal Republic of Germany \\ Received March 3, 1989; Revised Manuscript Received July 14, 1989
}

\begin{abstract}
We describe the first example of a mitochondrial protein with a covalently attached phosphatidylinositol moiety acting as a membrane anchor. The protein can be metabolically labeled with both stearic acid and inositol. The stearic acid label is removed by phospholipase D whereupon the protein with the retained inositol label is released from the membrane. This protein is a cAMP receptor of the yeast Saccharomyces cerevisiae and tightly associated with the inner mitochondrial membrane. However, it is converted into a soluble form during incubation of isolated mitochondria with $\mathrm{Ca}^{2+}$ and phospholipid (or lipid derivatives). This transition requires the action of a proteinaceous, $N$-ethylmaleimide-sensitive component of the intermembrane space and is accompanied by a decrease in the lipophilicity of the cAMP receptor. We propose that the component of the intermembrane space triggers the amphitropic behavior of the mitochondrial lipid-modified cAMP-binding protein through a phospholipase activity.
\end{abstract}

$\mathbf{O}$ nly in recent years specific fatty acids have been recognized to play important roles in the association of proteins with membranes. Both noncovalent and covalent interactions between fatty acids and proteins have been reported. Among the latter are GTP-binding proteins (Molenaar et al., 1988), ras proteins (Fujiama \& Tamanoi, 1986; Deschenes \& Broach, 1987), tyrosine kinases like p60 $0^{\text {src }}$ (Buss et al., 1984), cell surface receptors like IGF receptor II and cation-independent mannose 6-phosphate receptor (Morgan et al., 1987; Westcott \& Rome, 1988), murine T-cell-specific surface antigen Thy 1 (Tse et al., 1985), trypanosomal coat protein VSG (Schmitz et al., 1987), mammalian plasma membrane enzymes like alkaline phosphatase and 5'-nucleotidase (Jemmerson \& Low, 1987), human carcinoembryonic antigen (Takami et al., 1988a), and the decay accelerating factor of complement (Medof et al., 1986).

Fatty acids may be attached directly via oxyester or thioester bonds (Willumsen et al., 1984; Chen et al., 1985), the latter often being the case for ras and ras-related proteins in yeast as well as in mammals (Buss \& Sefton, 1986) and several GTP-binding proteins in mammals [for review, see Barbacid (1987)]. Kinetic analyses showed that the palmitylated polypeptides ankyrin and anion transporter are continuously acylated and deacylated at the erythrocyte plasma membrane (Staufenbiel, 1988). The deacylation reaction was not simply due to a chemical instability of the acyl groups but appeared to be physiologically induced, suggesting that reversible palmitylation of proteins may serve to modulate the protein's function and intracellular location.

The fatty acid may also be bound indirectly via a complete lipid side chain covalently attached to the protein. Most commonly found is phosphatidylinositol glycan (Cross, 1987; Low, 1987), which anchors proteins to the extracellular face of the plasma membrane. This structure is added post-

\footnotetext{
${ }^{+}$This work was supported by a grant from the Deutsche Forschungsgemeinschaft to W.B.

* Address correspondence to this author at the Laboratorium für molekulare Zellbiologie und allgemeine Pathologie der Universität Ulm.

†Universität Ulm.

Universität München.
}

translationally to many plasma membrane proteins in mammals [e.g., alkaline phosphatase (Ogata et al., 1988)], Trypanosoma brucei [variant surface glycoproteins (Ferguson et a1., 1985; Menon et al., 1988)], Dictyostelium discoideum [contact site A glycoprotein (Stadler et al., 1989)], and yeast (Conzelmann et al., 1988). However, in all cases where lipids are responsible for membrane anchoring of proteins, it is unclear whether their attachment is regulated and thereby controls a dual location of the protein or whether the lipid modification exclusively represents a step in the biosynthesis of this type of membrane protein for a unique location (Bangs et al., 1985). Removal of a lipid membrane anchor has not been observed in vivo, but in the case of the membrane-associated cytoskeletal protein $\alpha$-actinin (Burn, 1988) and of some eucaryotic plasma membrane proteins [alkaline phosphatase (Low \& Prasad, 1988); trypanosomal VSG (Cardoso de Almeida \& Turner, 1983; Bülow \& Overath, 1986)], it has been speculated that both covalent modification by a lipid and its removal by lipase action may be involved in the association with and dissociation from the plasma membrane, respectively.

Up to now, covalent lipid modification seemed to be restricted to plasma membrane proteins (Low \& Saltiel, 1988) whereas acylation of proteins with long-chain fatty acids was also reported for some membrane-associated proteins of the Golgi complex (Segev et al., 1988) and of secretory vesicles (Goud et al., 1988). Mitochondria have so far not been observed to harbor proteins embedded into their membranes via a fatty acid or a complete lipid moiety.

In an accompanying paper we demonstrate that a cAMP'-binding protein in mitochondria of the yeast $\mathrm{Sac}$ charomyces cerevisiae is amphitropic and occurs in a membrane-bound as well as in a soluble version (Müller \& Bandlow, 1989a). Surprisingly, both forms exhibit the same apparent molecular weight, indicating that release from the membrane is not effected by proteolysis. Here we present evidence that this protein is anchored in the inner membrane via a covalently linked inositol-containing phospholipid, in-

\footnotetext{
${ }^{1}$ Abbreviations: see accompanying paper (Müller \& Bandlow, 1989a).
} 
troducing a new type of protein attachment to mitochondrial membrane. In addition, a protein of the intermembrane space and a phospholipase activity were found to be responsible for the $\mathrm{Ca}^{2+}$ - and phospholipid-controlled release of the cAMP receptor into the intermembrane space.

\section{Materials AND MethodS}

Materials. Phospholipases $\mathrm{A}_{2}$ (bee venom), C (Bacillus cereus), and D (cabbage), esterase (pig liver), and RNase A were purchased from Boehringer, Mannheim; urographin was bought from Schering AG, Berlin; $\left[1-{ }^{14} \mathrm{C}\right]$ stearic acid 60 $\mathrm{mCi} / \mathrm{mmol})$, myo- $\left[2-{ }^{3} \mathrm{H}\right]$ inositol $(15 \mathrm{Ci} / \mathrm{mmol})$, and $N$ $\left[{ }^{3} \mathrm{H}\right]$ acetylconcanavalin $\mathrm{A}(45 \mathrm{Ci} / \mathrm{mmol})$ were provided by Amersham-Buchler, Braunschweig; $N$-ethylmaleimide and hydroxylamine were from Sigma, Taufkirchen; all other chemicals were obtained as described (Müller \& Bandlow, 1989a).

Yeast Strains, Growth Conditions, and Preparation of Mitochondria. Mitochondria were prepared from the protease-deficient yeast strain ABYS-66 (haploid), grown at 30 ${ }^{\circ} \mathrm{C}$ in lactate medium (Daum et al., 1982) and subsequently purified by equilibrium density centrifugation on $28 \%$ Percoll gradient (Müller \& Bandlow, 1989a).

Metabolic Labeling of the cAMP-Binding Protein. Yeast strain PEP4-3 was grown overnight at $30^{\circ} \mathrm{C}$ in semisynthetic SD medium (Wickerham, 1946) containing $50 \mathrm{mM}(\mathrm{NH})_{2} \mathrm{SO}_{4}$ as $\mathrm{N}$ source, $2 \%$ glucose as $\mathrm{C}$ source, and $10 \mu \mathrm{M}$ myo-inositol and harvested $\left(\mathrm{OD}_{600}=1.0\right)$. The pellet was resuspended in 10 volumes of SD medium with $2.5 \%$ lactate instead of glucose. After growth for $6 \mathrm{~h}$ at $30^{\circ} \mathrm{C}\left(\mathrm{OD}_{600}=0.4\right)$, cells were collected by centrifugation. For labeling with fatty acids, cells corresponding to $10-15 \mathrm{OD}_{600}$ were incubated in $2 \mathrm{~mL}$ of SD medium in the presence of $1 \mathrm{mCi}$ of $\left[1-{ }^{14} \mathrm{C}\right]$ stearic acid $(2 \mathrm{~h}$, $30^{\circ} \mathrm{C}$ ) (stearic acid in toluene was added to glass tubes and dried under $\mathrm{N}_{2}$, SD medium was added, and the fatty acid was suspended by mild sonication for $15 \mathrm{~min}$ before addition of cells). For labeling with myo-inositol, cells were incubated in $2 \mathrm{~mL}$ of myo-inositol-free SD medium with $0.5 \mathrm{mCi}$ of myo- $\left[2-{ }^{3} \mathrm{H}\right]$ inositol. The labeling reactions were terminated by the addition of a 100 -fold molar excess of unlabeled stearic acid or inositol, respectively, and by placing the tubes on ice. Mitochondria were prepared, incubated with or without $\mathrm{Ca}^{2+}$ and TPA, supplemented with EGTA (final concentration 100 $\mu \mathrm{M})$, spun through a cushion of $0.4 \mathrm{M}$ sucrose $\left(10 \mathrm{~min}, 4^{\circ} \mathrm{C}\right.$, $20000 \mathrm{rpm}$, Beckman TL-100, swing-out rotor), resuspended ( $2 \mathrm{mg} / \mathrm{mL}$ in binding buffer plus $0.5 \%$ MEGA 10 ), homogenized by ten strokes in a tightly fitting Dounce homogenizer, and centrifuged $\left(10 \mathrm{~min}, 4^{\circ} \mathrm{C}, 250000 \mathrm{~g}\right)$. The supernatant was applied to a cAMP-Sepharose column (Müller \& Bandlow, 1989b). After being washed with binding buffer, the protein was eluted with $0.1 \mathrm{M}$ cAMP and concentrated by precipitation with $30 \%$ PEG 4000 .

Subfractionation of mitochondria, the cAMP-binding assay, photoaffinity labeling, and polyacrylamide gel electrophoresis were carried out as described (Müller \& Bandlow, 1987a,b, 1989a). The $\mathrm{Ca}^{2+}$ phospholipid-controlled releasing reaction was routinely carried out in the presence of $50 \mu \mathrm{M} \mathrm{Ca}^{2+}$ and $0.5 \mu \mathrm{g} / \mathrm{mL}$ TPA for $10 \mathrm{~min}$ at $25^{\circ} \mathrm{C}$.

\section{RESULTS}

Calcium/Phospholipid-Controlled Release of the cAMPBinding Protein Is Mimicked by Treatment of Mitoplasts with Phospholipase. The preceding paper describes a mitochondrial cAMP-binding protein which normally behaves as an integral membrane protein but can be released into the soluble intermembrane space upon treatment of isolated mitochondria
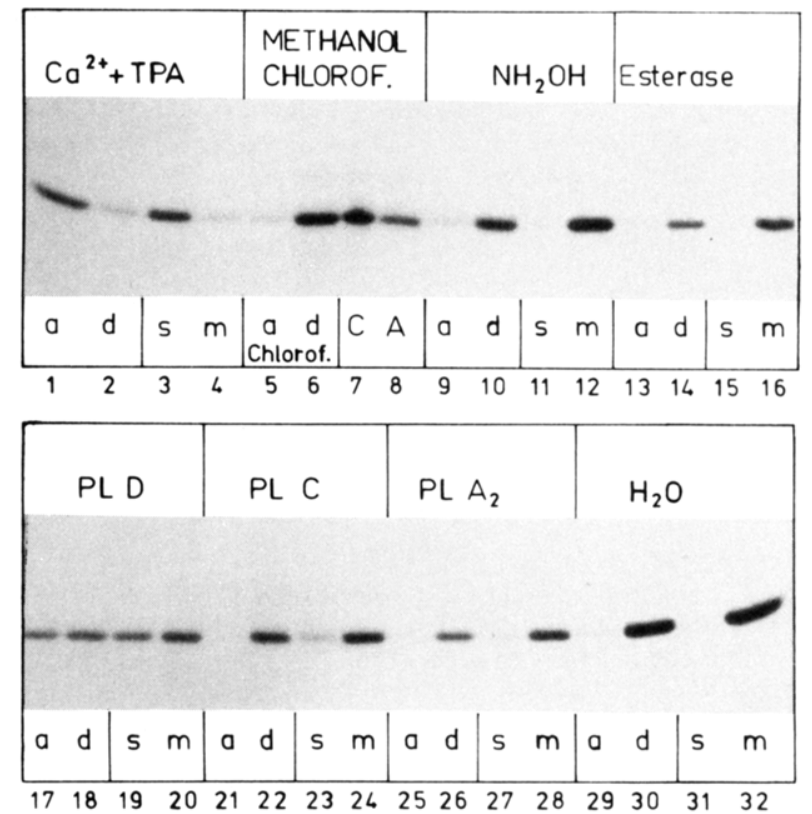

FIGURE 1: Lipolytic treatment of the cAMP-binding protein. The outer membrane of photoaffinity labeled mitochondria was disrupted by limited osmotic shock (Müller \& Bandlow, 1989a). Eight aliquots of "shocked mitochondria" (in a volume of $300 \mu \mathrm{L}$ each) were treated with $\mathrm{Ca}^{2+}$ plus TPA, $\mathrm{H}_{2} \mathrm{O}, 40$ units $/ \mathrm{mL}$ phospholipase $\mathrm{A}_{2}\left(\mathrm{PL} \mathrm{A}_{2}\right)$ (20 mM MOPS/KOH, pH 8.0, $5 \mathrm{mM} \mathrm{MgCl}$ ), 50 units/mL phospholipase C (PL C) (20 mM MOPS/KOH, pH 8.0, $2 \mathrm{mM} \mathrm{ZnCl}{ }_{2}$ ), 50 units/mL phospholipase D (PL D) (20 mM KP, pH 5.6, $75 \mathrm{mM}$ $\left.\mathrm{CaCl}_{2}\right), 25$ units $/ \mathrm{mL}$ esterase $(25 \mathrm{mM} \mathrm{MES} / \mathrm{KOH}, \mathrm{pH} 6.2,30 \mathrm{~min}$, $\left.30{ }^{\circ} \mathrm{C}\right), 1 \mathrm{M} \mathrm{NH}{ }_{2} \mathrm{OH}\left(60 \mathrm{~min}, 37^{\circ} \mathrm{C}\right)$, or 2 volumes of chloroform/methanol $\left(2: 1, \mathrm{pH} 5.5,\left(10 \mathrm{~min}, 0^{\circ} \mathrm{C}\right)\right.$. The last sample was centrifuged, and the chloroform (C) and aqueous phases (A) were separated, dried under vacuum, and dissolved in binding buffer plus $0.5 \%$ MEGA 10 (Müller \& Bandlow, 1989a). Half received 2 volumes of double-strength sample buffer and was analyzed directly by SDS-PAGE (20\%). With the other half (only $\mathrm{CHCl}_{3}$ phase shown) the partitioning behavior in TX-114 was studied. All other samples were made $25 \mathrm{mM}$ in EDTA. Half was separated into membranes (m) and soluble proteins (s) by two-step sucrose gradient centrifugation. The other half received 1 volume of $2 \%$ TX-114 and was separated into aqueous (a) and detergent phases (d). All samples were precipitated with 5\% TCA and analyzed by SDS-PAGE (20\%) and fluorography.

with $\mathrm{Ca}^{2+}$ and phospholipids or TPA. This release is accompanied by a drastic increase in the protein's hydrophilicity whereas its apparent molecular weight remains unaltered. Therefore, it is very unlikely that the cAMP receptor is released by $\mathrm{Ca}^{2+} /$ phospholipid-dependent proteolytic removal of a hydrophobic transmembrane domain, through which integral membrane proteins are most commonly anchored in membranes.

Fatty acids or lipid moieties can act as membrane-anchoring structures of proteins. They are likely to escape detection by SDS-PAGE. Thus, we first studied whether any chemical or enzymic treatment, causing removal of fatty acids or lipids, mimicks the effect of $\mathrm{Ca}^{2+}$ plus TPA on the release of the cAMP receptor from the inner membrane (Figure 1). Outer membranes of $8-\mathrm{N}_{3}-\left[{ }^{32} \mathrm{P}\right]$ cAMP photoaffinity labeled mitochondria were disrupted by limited osmotic shock to gain access for exogenously added enzymes to the outer face of the inner membrane. Subsequently these "shocked mitochondria" were incubated with $\mathrm{Ca}^{2+}$ and TPA or subjected to chemical and enzymic lipolysis. Half of each sample was separated into mitoplasts and intermembrane space proteins. The other half was partitioned into aqueous and TX-114 phases.

As expected, most of the photoaffinity labeled protein in untreated mitoplasts (lanes 29-32) was found associated with 


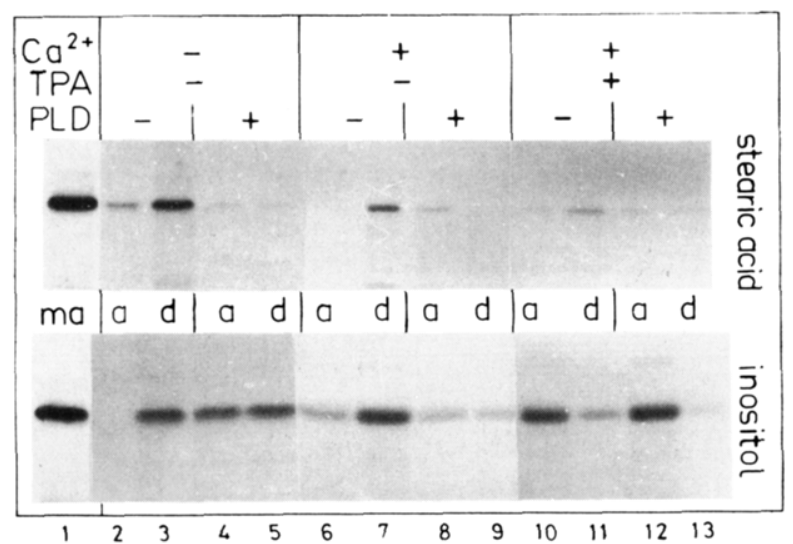

FIGURE 2: Metabolic labeling of the cAMP-binding protein. Aliquots of mitochondria, metabolically labeled with either $\left[{ }^{3} \mathrm{H}\right]$ inositol or $\left[{ }^{14} \mathrm{C}\right]$ stearic acid, were shocked, treated with or without $\mathrm{Ca}^{2+}$ and TPA, and then solubilized with $0.5 \%$ MEGA 10 , and the cAMP-binding protein was enriched by cAMP-Sepharose affinity chromatography. One aliquot of each eluate was incubated with phospholipase D; the other remained untreated. After partitioning in $\mathrm{H}_{2} \mathrm{O}$ /Triton X-114, the aqueous (a) and detergent (d) phases were analyzed by SDSPAGE and fluorography. 8- $\mathrm{N}_{3}-\left[{ }^{32} \mathrm{P}\right]$ cAMP affinity labeled cAMPbinding protein was run in a parallel lane on the same gel (ma).

the membrane fraction (lane 32) and recovered from the detergent phase after partitioning (lane 30). Similarly, acidic chloroform/methanol extraction of the membranes (lanes 5-8) which solubilized a significant portion of the receptor (lane 7) did not increase the portion of cAMP-binding protein in the aqueous phase (lane 5). Thus the lipophilic membrane anchor appears to be covalently attached to the protein moiety of the receptor. This contrasts to the $\mathrm{Ca}^{2+} /$ TPA-controlled release of the receptor (lanes 1-4): most of the protein was found in the soluble fraction after this treatment (lane 3). Consequently, the recovery from the aqueous phase after partitioning (lane 1) argued that the released version was hydrophilic and thus had lost the membrane anchor during the $\mathrm{Ca}^{2+} /$ TPA treatment. We then assayed whether also hydroxylamine, esterase, or various phospholipases are able to release the protein from the membrane with concomitant decrease of its lipophilicity. Alkaline hydroxylamine was inefficient (lanes 9-12), suggesting that the cAMP-binding protein is not acylated with fatty acids via thioester bonds. Oxyester linkage was excluded by an experiment where mitoplasts were treated with esterase (lanes 13-16). The receptor was retained in the mitoplast fraction (lane 16) or in the detergent phase, respectively (lane 14). However, phospholipase $D$ (lanes 17-20), but not phospholipases $A_{2}$ and $C$ (lanes 21-28), solubilized about $50 \%$ of the membrane-bound receptor protein (lane 19) with a concomitant increase in hydrophilicity to about the same degree (lane 17). This is a first indication of a covalently bound lipid structure that functions as a membrane anchor for the cAMP receptor.

cAMP-Binding Protein Carries a Phosphatidylinositol Anchor, Which Is Removed by Phospholipase D and $\mathrm{Ca}^{2+} /$ TPA Treatment. The release of the cAMP receptor protein from the inner mitochondrial membrane by phospholipase $D$ would predict that the membrane-embedded form of the receptor contains phosphatidic acid which is absent from the soluble version. On the other hand, both forms should contain the specific alcohol head group linked to the protein moiety. A metabolic labeling experiment shows that this is, in fact, the case (Figure 2).

Yeast cells were grown in the presence of radiolabeled stearic acid or inositol. Isolated mitochondria were treated with or without $\mathrm{Ca}^{2+}$ and TPA, solubilized, and subjected to
cAMP affinity chromatography (Müller \& Bandlow, 1989b). Each eluate was divided into halves which were incubated with phospholipase D or remained untreated. Both were subsequently analyzed by TX-114 partitioning. Since the metabolically labeled and cAMP affinity purified protein and the authentic photoaffinity labeled cAMP receptor showed very similar elution profiles during gel filtration chromatography (data not shown), both proteins seemed to be identical. This view was strengthened by the comigration of the two radiolabeled "receptor preparations" during SDS-PAGE (Figure 2 , compare lane 1 with the other lanes) and by the many electrophoretically identical peptides, radiolabeled with 8$\mathrm{N}_{3}$-cAMP or inositol, respectively, which they share after partial proteolysis with endoprotease V8 (data not shown).

Figure 2 shows that the membrane-associated cAMP receptor, recovered mainly from the detergent phase, carried stearic acid label as well as inositol label (lane 3). Phospholipase $\mathrm{D}$ action strongly diminished the stearic acid label but not the inositol label (lanes 4 and 5), which, however, was about equally distributed between the detergent (lane 5) and the aqueous phase (lane 4) during partitioning. Thus the membrane anchor of the cAMP receptor seems to consist of or, at least, to contain phosphatidylinositol, the glycerol being esterified with stearic acid. Next we examined whether the $\mathrm{Ca}^{2+} /$ phospholipid-controlled amphitropic behavior of the receptor involves the cleavage of this lipid moiety.

Stearic acid labeled as well as inositol-labeled cAMP receptor was also observed in $\mathrm{Ca}^{2+}$-treated mitochondria (lane 7). However, a minor portion of the inositol-labeled receptor could now be recovered from the aqueous phase (lane 6), as has been found for the photoaffinity labeled receptor protein (Müller \& Bandlow, 1989a). After treatment with $\mathrm{Ca}^{2+}$ plus TPA almost no stearic acid could be detected associated with the protein (lanes 10 and 11). Again, incorporation of inositol was not affected, although the major portion of the inositollabeled receptor was now found in the aqueous phase (lane 10). The increased proportion of water-soluble inositol-labeled receptor correlated well with the observed decrease in stearic acid labeled protein. Phospholipase D slightly increased the proportion of inositol-labeled protein recovered from the aqueous phase of $\mathrm{Ca}^{2+} /$ TPA-treated mitochondria (lane 12). The electrophoretic analysis of phospholipase D treated cAMP receptor revealed that the removal of the (stearic acid containing) phosphatidyl residue did not lead to a change in the apparent molecular weight of the (inositol labeled) cAMP receptor as compared to the photoaffinity of inositol-labeled membrane-bound receptor (lanes 1 and 3). Taken together, the $\mathrm{Ca}^{2+} /$ TPA treatment and the phospholipase $\mathrm{D}$ action cause removal of stearic acid, presumably as phosphatidic acid, but leave the inositol moiety linked to the cAMP receptor. Upon lipolysis the hydrophilicity of the receptor increases. These data support the view that a phospholipase activity triggers the $\mathrm{Ca}^{2+} /$ TPA-controlled amphitropic behavior of the mitochondrial cAMP-binding protein.

Calcium/Phospholipid-Controlled Release of the cAMPBinding Protein Is Enzymatically Catalyzed. The deduced nature of the membrane anchor of the cAMP receptor and its liberation into the intermembrane space by phospholipase D action suggested an enzymatically catalyzed releasing reaction under the control of $\mathrm{Ca}^{2+}$ and phospholipids. We tested for the existence of a mitochondrial releasing activity and its possible association with the inner membrane or residence within the intermembrane space, locations which both would permit access to the putative cleavage site within the lipid moiety of the receptor at the outer face of the inner membrane. 

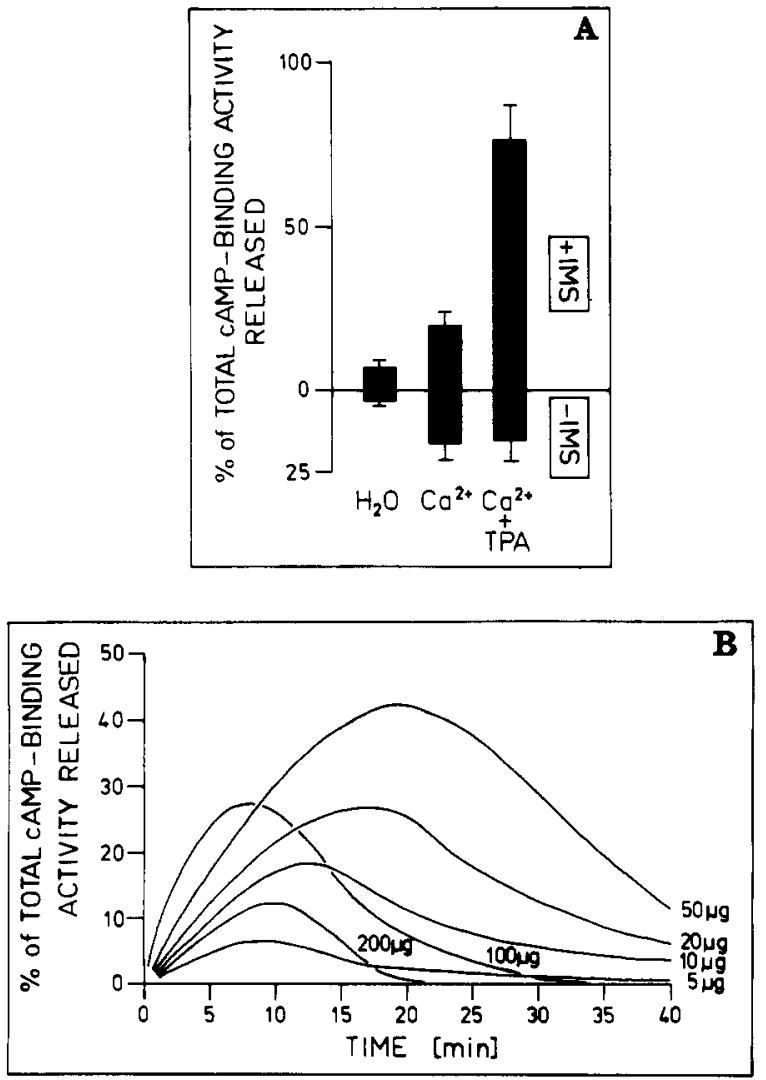

FIGURE 3: (A) Effect of the intermembrane space on the release of the cAMP receptor. Mitochondria were separated into mitoplasts and intermembrane space. The intermembrane space fraction was precipitated ( $30 \%$ PEG $4000,15 \mathrm{~min}, 0^{\circ} \mathrm{C} / 5 \mathrm{~min}$, microfuge) and dissolved (10 $\mathrm{mg} / \mathrm{mL}$ in binding buffer). Purified mitoplasts received either $120 \mu \mathrm{g}$ of intermembrane space fraction (+IMS) or received buffer (-IMS). Aliquots of both samples were incubated in the presence or absence of $\mathrm{Ca}^{2+}$ and TPA and subsequently separated into mitoplasts and soluble proteins by two-step sucrose gradient centrifugation. The soluble proteins were precipitated by $30 \%$ PEG 4000 , dissolved, and desalted by passage through a $0.5-\mathrm{mL}$ column of Sephadex G-25. All samples were tested for cAMP-binding activity. The released cAMP-binding activity, measured in the supernatant, is given as the percentage of total cAMP binding of mitoplasts and soluble proteins. $100 \%$ cAMP binding is $0.25 \mathrm{pmol}$ of $\mathrm{cAMP} / \mathrm{mg}$ of protein in this experiment. (B) Kinetics of the release of the cAMP-binding protein. Aliquots of mitoplasts $(250 \mu \mathrm{g})$ were incubated each with $5,10,20,50,100$, or $200 \mu \mathrm{g}$ of intermembrane space protein (see legend to Figure 4) in the presence of $\mathrm{Ca}^{2+}$ plus TPA. After $2-, 5-, 10-, 15-, 20-, 25-, 30-$, and $40-\mathrm{min}$ incubation at $25^{\circ} \mathrm{C}$ aliquots of the mixtures were removed, supplemented with EGTA, cooled to $0^{\circ} \mathrm{C}$, and separated into mitoplasts and soluble proteins by two-step sucrose gradient centrifugation. All samples were further processed and assayed for CAMP-binding activity as described for (A). $100 \%$ cAMP-binding is $0.31 \mathrm{pmol}$ of $\mathrm{CAMP} / \mathrm{mg}$ of protein in this experiment.

For this purpose, photoaffinity labeled mitoplasts were treated with $\mathrm{Ca}^{2+}$ and TPA in the presence or absence of soluble proteins of the intermembrane space. Figure $3 \mathrm{~A}$ shows that the release of the cAMP-binding protein, effected by $\mathrm{Ca}^{2+}$ alone, did not depend on the presence of intermembrane space proteins. By contrast, the efficient $\mathrm{Ca}^{2+} / \mathrm{TPA}$-controlled solubilization strictly required the presence of a fraction of the intermembrane space. In its absence only the TPA-independent release occurred.

To corroborate the enzymic nature of the releasing activity and its location in the soluble intermembrane space, we examined whether the efficiency of the intermembrane space fraction dependent releasing reaction depends on time and amount of this fraction present during the incubation. Purified mitoplasts were supplemented with increasing concentrations of intermembrane space fraction and incubated for variable

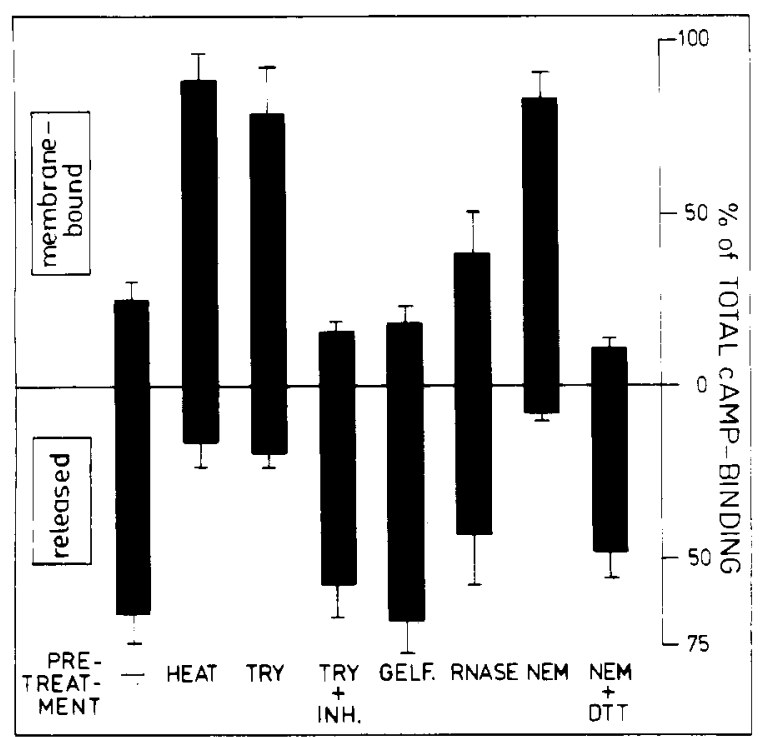

FIGURE 4: Protein nature of the releasing factor. Aliquots of mitoplasts (200 $\mu \mathrm{g}$ each) were supplemented with $40 \mu \mathrm{g}$ of intermembrane space fraction which had been preincubated with heat $\left(5 \mathrm{~min}, 95^{\circ} \mathrm{C}\right), 10$ $\mu \mathrm{g} / \mathrm{mL}$ RNase A $\left(15 \mathrm{~min}, 20^{\circ} \mathrm{C}\right), 50 \mu \mathrm{g} / \mathrm{mL}$ trypsin (TRY) in the absence or presence of a 4-fold molar excess of soy bean trypsin inhibitor plus $200 \mu \mathrm{M}$ PMSF (INH) $\left(60 \mathrm{~min}, 0^{\circ} \mathrm{C}\right)$, on $1 \mathrm{mM}$ $N$-ethylmaleimide (NEM) in the absence or presence of $2 \mathrm{mM}$ DTT $\left(15 \mathrm{~min}, 0^{\circ} \mathrm{C}\right)$ or had remained untreated. The trypsin or NEM treatment of intermembrane space proteins was stopped prior to their addition to mitoplasts by incubation with trypsin inhibitor plus PMSF or DTT, respectively (see above). One aliquot was supplemented with $40 \mu \mathrm{g}$ of intermembrane space protein which had been passed through a 1-mL column of Sephadex G-10 (GELF.). Subsequently, all samples were incubated with $\mathrm{Ca}^{2+}$ plus TPA, separated into mitoplasts (membrane bound) and soluble proteins (released) by two-step sucrose gradient centrifugation, and analyzed for released cAMP-binding activity. $100 \%$ of total cAMP-binding refers to $0.35 \mathrm{pmol}$ of $\mathrm{cAMP} / \mathrm{mg}$ of protein in the unfractionated incubation mixture.

periods of time. The mixtures were subsequently separated into mitoplasts and soluble proteins. Both fractions were assayed for cAMP-binding activity. Figure 3B reveals that, with up to $50 \mu \mathrm{g}$ of intermembrane space fraction per $250 \mu \mathrm{g}$ of mitoplasts, the velocity of the releasing reaction $(7 \mathrm{~min}$ for half-maximal release) was linear with time (up to $10 \mathrm{~min}$ ) and yielded maximum release (up to $42 \%$ of the initial cAMPbinding activity); $100 \mu \mathrm{g}$ of intermembrane space fraction caused a further increase of the reaction velocity but strongly reduced linearity with time and maximum release. Still higher amounts inhibited the release of the CAMP receptor. Incubation times longer than 20 min diminished the cAMP-binding activity. This agrees well with the observed loss of activity due to the rapid proteolytic turnover of the protein after $\mathrm{Ca}^{2+} /$ TPA treatment of whole mitochondria (Müller \& Bandlow, 1989a). The portion of released receptor observed both in the reconstituted system and in the assay using whole mitochondria was comparable. Since the intermembrane space contributes only about $10 \%$ to the total mitochondrial protein, either the amount of active releasing factor is limiting in mitochondria, or our reconstituted assay works less efficiently than whole mitochondria. Taken together, the time course and dependence on the amount of intermembrane space fraction strongly argue for an enzymic (releasing) activity in that compartment which mediates the $\mathrm{Ca}^{2+} /$ phospholipidcontrolled conversion of the membrane-bound form into the soluble form of the receptor.

Calcium/Phospholipid-Controlled Release of the CAMPBinding Protein Requires a Protein of the Intermembrane Space. We attempted to characterize the nature of the releasing activity in the intermembrane space. Figure $4 \mathrm{dem}$ - 
onstrates its proteinaceous character. Mitoplasts were incubated with constant amounts of intermembrane space fraction $(50 \mu \mathrm{g})$. Pretreatment of intermembrane space proteins with heat, trypsin, and NEM completely inhibited release of the receptor from the membrane. By contrast, trypsin in the presene of inhibitor, NEM quenched with DTT, RNase, or gel filtration, which would remove low molecular weight components, had almost no effect. Thus at least one soluble NEM-sensitive protein of the intermembrane space, termed releasing factor, participates in the releasing process by ultimately causing-either in a direct or regulatory fashioncleavage of the lipid anchor of the cAMP receptor.

\section{Discussion}

The cAMP-binding protein in mitochondria of the yeast Saccharomyces cerevisiae represents the first case of an intracellular protein which is bound to a biological membrane via a covalently attached lipid moiety. It can be metabolically labeled with inositol and stearic acid. The fatty acid label but not the inositol label is removed by phospholipase $\mathrm{D}$ action. These features are characteristic for an inositol-containing phospholipid esterified with stearic acid. Up to now, this type of membrane anchor has been described only for several eucaryotic extracellularly exposed plasma membrane proteins [for review, see Low (1987)].

It is unclear why only stearic acid is efficiently incorporated in to the cAMP receptor protein in contrast to palmitic acid (data not shown), since the latter one is 4-fold more abundant in yeast mitochondria (Paltauf \& Schatz, 1969). Fatty acids may differ in their uptake rates into yeast mitochondria or intracellular pools (Daum, 1985). The mitochondrial cAMP receptor appears to be linked exclusively to phosphatidylinositol since radiolabeled ethanolamine ${ }^{2}$ and choline could not be detected in this protein after metabolic labeling (data not shown). Phosphatidylinositol accounts only for about $8 \%$ of total phospholipids in the yeast inner mitochondrial membrane (Bottema \& Parks, 1980).

The chemical nature of the linkage between the inositol moiety and the protein remains to be elucidated. In eucaryotic plasma membrane proteins having a lipid membrane anchor, the phosphatidylinositol is coupled via a complex glycan structure through an ethanolamine bridge to the carboxy terminus of the protein (Rose et al., 1984; Ferguson et al., 1988). Alternatively, the alcoholic head group of phosphatidylinositol may be linked via a phosphodiester bridge to internal hydroxylated amino acids of the protein. This type of linkage would be more compatible with the mitochondrial location of the cAMP receptor since glycosylation seems to be restricted to lipids and proteins moving along the secretory pathway (Palade, 1975). The absence of glycosyl residues might also explain the inability of the bacterial toxin phosphoinositol glycan specific phospholipase $C$ to cleave the receptor into diacylglycerol and the phosphoryl-inositol-protein moiety (Bangs et al., 1986).

Phospholipase D effects membrane release of the cAMP receptor. Concomitantly, the protein's hydrophilicity increases. Thus the anchoring of the cAMP receptor in the inner mitochondrial membrane appears to be accomplished solely by the inositol phospholipid. The existence of this type of mitochondrial membrane protein raises some intriguing questions about its biosynthesis. In higher eucaryotes, glycophospholipid-anchored plasma membrane proteins are synthesized as precursors with a short stretch of hydrophobic amino acids

\footnotetext{
${ }^{2}$ Ethanolamine labeling of the cAMP receptor protein was, however, observed with $\mathrm{CHO}$ cells ( $G$, Müller, unpublished results)
}

at the C-terminus (Boothroyd et al., 1980; Cross, 1984; Seki et al., 1985; Oikawa et al., 1987; Berger et al., 1988) which does not appear in the mature phosphatidylinositol glycan tailed product. This domain is believed to transiently span the membrane of the endoplasmic reticulum as the protein starts its way along the secretory pathway to the cell surface (Takami et al., 1988b) and to be ultimately replaced by the prefabricated core glycolipid anchor (Menon et al., 1988) in a pseudotranspeptidation reaction (Bangs et al., 1985; Krakow et al., 1986). The amino acid sequence deduced from the gene for the mitochondrial cAMP receptor will reveal whether it exhibits similar sequence prerequisites and mechanisms for phospholipid attachment as plasma membrane proteins (Caras et al, 1987, 1989). Interestingly, extracellular lipoproteins of Gram-positive bacteria which exhibit homology to soluble periplasmic sugar- and oligopeptide-binding proteins in Gram-negative bacteria (Dudler et al., 1988; Gilson et al., 1988 ) become attached to the plasma membrane via a glyceride moiety linked to the $\mathrm{N}$-terminal cysteine of the mature protein after transient membrane anchoring by the signal peptide. It was also suggested that this "lipoprotein modification offers the Gram-positive bacterium an efficient way of retaining a variable portion of its secreted proteins in an active releasable form" (Nielsen \& Lampen, 1982).

The degradation of phospholipid-modified proteins requires phospholipases. Such enzymes are present in all cellular membranes. $\mathrm{Ca}^{2+}$-independent phospholipase $\mathrm{A}_{1}$ from rat heart mitochondria is associated with the outer face of the outer membrane (Palmer et al., 1981), whereas $\mathrm{Ca}^{2+}$-dependent phospholipase $A_{2}$ is located within the matrix/intermembrane space (Cheah \& Cheah, 1981). Here we describe an enzymic activity in yeast mitochondria which exhibits phospholipase action. The data, obtained from metabolic labeling experiments, are compatible with phospholipase A, $\mathrm{C}$, or $\mathrm{D}$ action. The mitochondrial phospholipase activity is observed only in the presence of $\mathrm{Ca}^{2+}$, phospholipid (or lipid derivatives), and NEM-sensitive protein(s) of the intermembrane space (releasing factor). This suggests a location of the enzyme itself and/or regulatory components in that compartment. From the experiments presented so far it remains open whether $\mathrm{Ca}^{2+}$, phospholipids, and the releasing factor(s) participate altogether in the lipolytic cleavage reaction or affect mechanistically different steps of the releasing process. In an accompanying paper we succeeded in separating a $\mathrm{Ca}^{2+}$-dependent posttranslational modification of the cAMP-binding protein from the phosholipid-dependent activation of the mitochondrial phospholipase (Müller \& Bandlow, 1989b).

The described lipolytic activity is, most likely, not or not only involved in the degradation of the mitochondrial cAMP receptor but probably plays an important role in controlling its intramitochondrial location. The soluble cAMP-binding protein, released into the intermembrane space by the mitochondrial phospholipase, may regulate certain mitochondrial functions by converting a cAMP-dependent protein kinase to its activatable form (Müller \& Bandlow, 1987, 1989a). Analogously, extracellular phospholipases are believed to release mammalian phosphatidylinositol-anchored plasma membrane proteins from the cell surface into the blood stream where they exert their biological function (Fox et al., 1986; Hereld et al., 1986; Davitz et al., 1987). Thus, phospholipases may elicit physiological responses not only through the hydrolysis products of phospholipids but also by the (irreversible) liberation of phospholipid-modified proteins from biological membranes.

Registry No. Phospholipase, 9013-93-8. 


\section{REFERENCES}

Bangs, J. D., Hereld, D., Krakow, J. L., Hart, G. W., \& Englund, P. T. (1985) Proc. Natl. Acad. Sci. U.S.A. 82, 3207.

Bangs, J. D., Andrews, N. W., Hart, G. W., \& Englund, P. T. (1986) J. Cell. Biol. 103, 255.

Barbacid, M. (1987) Annu. Rev. Biochem. 56, 779.

Berger, J., Howard, A. D., Brink, L., Gerber, L., Hauber, J., Cullen, B. R., \& Udenfriend, S. (1988) J. Biol. Chem. 263, 10016.

Boothroyd, J. C., Cross, G. A. M., Hoeijmakers, J. H. J., \& Borst, P. (1980) Nature 288, 624.

Bottema, C. K., \& Parks, L. W. (1980) Lipids 15, 987.

Bülow, R., \& Overath, P. (1986) J. Biol. Chem. 261, 11918.

Burn, P. (1988) J. Cell. Biochem. 36, 15.

Buss, J. E., \& Senfton, B. M. (1986) Mol. Cell. Biol. 6, 116.

Buss, J. E., Kamps, M. P., \& Senfton, B. M. (1984) Mol. Cell. Biol. 4, 2697.

Caras, I. W., Weddell, G. N., Davitz, M. A., Nussenzweig, V., \& Martin, D. W. (1987) Science 238, 1280.

Caras, I. W., Weddell, G. N., \& Williams, S. R. (1989) J. Cell. Biol. 108, 1387.

Cardoso de Almeida, M. L., \& Turner, M. J. (1983) Nature $302,349$.

Cheah, K. S., \& Cheah, A. M. (1981) Biochim. Biophys. Acta $638,40$.

Chen. Z.-Q., Ulsh, L. S., Dubois, G., \& Shih, T. Y. (1985) J. Virol. 56, 607.

Conzelmann, A., Reizman, H., Chantal, D., \& Bron, C. (1988) EMBO J. 7, 2233.

Cross, G. A. M. (1984) Philos. Trans. R. Soc. London B307, 3.

Cross, G. A. M. (1987) Cell 48, 179.

Daum, G. (1985) Biochim. Biophys. Acta 822, 1.

Daum, G., Böhni, P. C., \& Schatz, G. (1982) J. Biol. Chem. 257, 13028.

Davitz, M. A., Hereld, D., Shak, S., Krakow, J., Englund, P. T., \& Nussenzweig, V. (1987) Science 238, 81.

Deschenes, R. J., \& Broach, J. R. (1987) Mol. Cell. Biol. 7, 2344.

Dudler, R., Schmidhauser, C., Parish, R. W., Wettenhall, R. E. H., \& Schmidt, T. (1988) EMBO J. 7, 3963.

Ferguson, M. A. J., Low, M. G., \& Cross, G. A. M. (1985) J. Biol. Chem. 260, 14547.

Ferguson, M. A. J., Homanns, S. W., Dwek, R. A., \& Rademacher, T. W. (1988) Science (in press).

Fox, J. A., Duszenko, M., Ferguson, M. A. J., Low, M. G., \& Cross, G. A. M. (1986) J. Biol. Chem. 261, 15767.

Fujiyama, A., \& Tamanoi, F. (1986) Proc. Natl. Acad. Sci. U.S.A. 83, 1266.

Gilson, E., Alloing, G., Schmidt, T., Claverys, J. P., Dudler, P., \& Hofnung, M. (1988) EMBO J. 7, 3971.

Goud, B., Salminen, A., Walworth, N. C., \& Novick, P. J. (1988) Cell 53, 753.

Hereld, D., Krakow, J. L., Bangs, J. D., Hart, G. W., \& Englund, P. T. (1986) J. Biol. Chem. 261, 12813.

Jemmerson, R., \& Low, M. G. (1987) Biochemistry 26, 5703.
Krakow, J. L., Hereld, D., Bangs, J. D., Hart, G. W., \& Englund, P. T. (1986) J. Biol. Chem. 26I, 12147.

Low, M. G. (1987) Biochem. J. 244, 1.

Low, M. G., \& Prasad, A. R. S. (1988) Proc. Natl. Acad. Sci. U.S.A. 85, 980.

Low, M. G., \& Saltiel, A. R. (1988) Science 239, 268.

Medof, M. E., Walter, E. I., Roberts, W. L., Haas, R., \& Rosenberg, T. L. (1986) Biochemistry 25, 6740.

Menon, A. K., Mayer, S., Ferguson, M. A. J., Duszenko, M., \& Cross, G. A. M. (1988) J. Biol. Chem. 263, 1970.

Molenaar, C. M. T., Prange, R., \& Gallwitz, D. (1988) EMBO $J .7,971$.

Morgan, D. O., Edman, J. C., Standring, D. N., Fried, V. A., Smith, M. C., Roth, R. A., \& Rutter, W. J. (1987) Nature 329, 301.

Müller, G., \& Bandlow, W. (1987a) Yeast 3, 161.

Müller, G., \& Bandlow, W. (1987b) Z. Naturforsch. 42C, 1291.

Müller, G., \& Bandlow, W. (1989a) Biochemistry (first paper of three in this issue).

Müller, G., \& Bandlow, W. (1989b) Biochemistry (third paper of three in this issue).

Nielsen, J. B. K., \& Lampen, J. O. (1982) J. Bacteriol. 152, 315.

Oikawa, S., Nakazato, H., \& Kosaki, G. (1987) Biochem. Biophys. Res. Commun. 142, 511.

Ogata, S., Hayashi, Y., Takami, N., \& Ikehara, Y. (1988) J. Biol. Chem. 263, 10489.

Palade, G. (1975) Proc. Natl. Acad. Sci. U.S.A. 84, 3288.

Palmer, J. W., Schmid, P. C., Pfeiffer, D. R., \& Schmid, H. H. O. (1981) Arch. Biochem. Biophys. 211, 674.

Paltauf, F., \& Schatz, G. (1969) Biochemistry 8, 335.

Rödel, G., Müller, G., \& Bandlow, W. (1985) J. Bacteriol. $161,7$.

Rose, J. K., Adams, G. A., \& Gallione, C. J. (1984) Proc. Natl. Acad. Sci. U.S.A. 81, 2050.

Schmitz, B., Klein, R. A., Duncan, I. A., Egge, H., Gunawan, J., Peter-Katalinic, J., Dabrowski, U., \& Dabrowski, J. (1987) Biochem. Biophys. Res. Commun. 146, 1055.

Segev, N., Mulholland, J., \& Botstein, D. (1988) Cell 52, 915.

Seki, T., Chang, H.-C., Moriuchi, T., Dinome, R., Ploegh, H., \& Silver, J. (1985) Science 227, 649.

Stadler, J., Keenan, T. W., Bauer, G., \& Gerisch, G. (1989) EMBO J. 8, 371.

Staufenbiel, M. (1988) J. Biol. Chem. 263, 13615.

Takami, N., Misumi, Y., Kuroki, M., Matsuoka, Y., \& Ikehara, Y. (1988a) J. Biol. Chem. 263, 12716.

Takami, N., Ogata, S., Oda, K., Misumi, Y., \& Ikehara, Y. (1988b) J. Biol. Chem. 263, 3016.

Tse, A. G. D., Barclay, A. N., Walts, A., \& Williams, A. F. (1985) Science 230, 1003.

Westcott, K. R., \& Rome, H. R. (1988) J. Cell. Biochem. 38, 23.

Wickerham. J. L. (1946) J. Bacteriol. 52, 293.

Willumsen, B. M., Norris, K., Papageorge, A. G., Hubbert, N. L., \& Lowy, D. R. (1984) EMBO J. 3, 2581. 